\title{
Distribution of Neotyphodium endophytes in naturalised ryegrasses (Lolium spp.) in Japan
}

\author{
M. YAMASHITA ${ }^{1}$, K. UCHIYAMA ${ }^{1}$, T. MATSUDA ${ }^{1}$, H. TOBINA ${ }^{2}$, \\ H. SAWADA ${ }^{1}$ and K.SUGAWARA ${ }^{3}$ \\ ${ }^{1}$ Faculty of Agriculture, Shizuoka University, Shizuoka, Japan \\ ${ }^{2}$ United Graduate School of Agricultural Science, Gifu University, Gifu, Japan \\ ${ }^{3}$ National Institute of Livestock and Grassland Science, Nasushiobara, Tochigi, Japan \\ abmyama@agr.shizuoka.ac.jp
}

\begin{abstract}
Introduced Lolium grasses are utilised in Japan for forage, turf and soil conservation. Many of these grasses have become naturalised in disturbed ecosystems. Neotyphodium endophytes in the tissues of grasses can increase host fitness by increasing tolerance to both biotic and abiotic stresses. Consequently, endophyte infection may be a factor enhancing invasion success of exotic grasses in the Japanese islands. We detected infection by Neotyphodium endophytes in 162 of 173 naturalised ryegrass populations in Japan. Italian ryegrass (L. multiflorum) had a higher infection rate than perennial ryegrass (L. perenne). Italian ryegrass also exhibited geographic variation in infection rate. It is unlikely that the infected Italian ryegrasses found in this study have come from cultivars used in meadows, since the use of forage ryegrass cultivars infected with Neotyphodium endophytes has been restricted in Japan to prevent toxicity problems. Possible sources of the ryegrasses may be turf seeds, soil conservation materials and/or contaminants in imported plant materials.

Keywords: alien species, invasive plants, Italian ryegrass, Lolium multiflorum, Neotyphodium endophyte, perennial ryegrass, Lolium perenne
\end{abstract}

\section{Introduction}

Introduced Lolium grasses are utilised in Japan for forage, turf and soil conservation. Many of these grasses have become naturalised in disturbed ecosystems such as riparian areas and some have become highly invasive in local plant communities and agroecosystems. As with many cool-season grasses, Lolium is often infected with endophytes of the genus Neotyphodium.

Figure 1 Frequency distribution of infection rate (\%) by Neotyphodium endophytes in naturalised Italian ryegrass (a) and perennial ryegrass (b) in Japan. A chi-square test shows significant difference between infection rates of these ryegrasses $\left(\chi^{2}=286, \mathrm{P}<0.005\right)$.

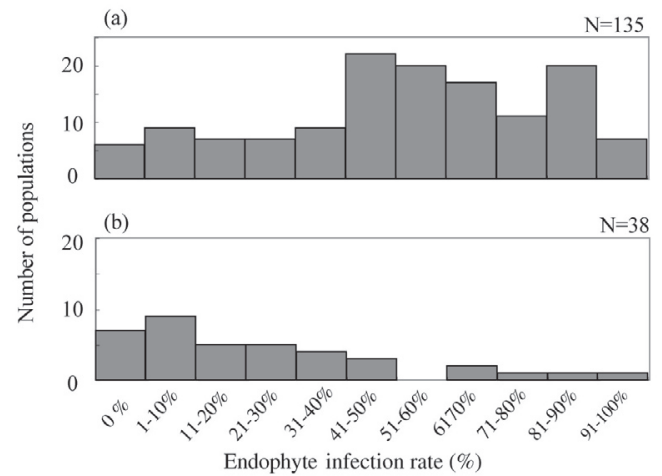

Italian ryegrass (Lolium multiflorum) has been extensively naturalised in native grasslands in the United States (Weiss 1999) and in the pampa grasslands of Argentina (Vila-Aiub et al. 2005). Vila-Aiub et al. (2005) showed that endophyte-infected Italian ryegrass produced significantly more vegetative tillers and allocated more biomass to roots and seeds than uninfected individuals. Because the endophytes of some grasses can increase host fitness by increasing tolerance to both biotic and abiotic stress, infection may be a factor promoting invasion success of alien grasses (Rudgers et al. 2004, 2005), which in turn may reduce diversity in native communities (Clay \& Holah 1999).

Neotyphodium-infected perennial ryegrass (L. perenne) was found in three surveys covering northern Japan, but the populations were not abundant and there were no toxicity problems for herbivorous animals (Koga et al. 1993; Sato et al. 1995; Saiga et al. 2003). Until recently, Neotyphodiuminfected Italian ryegrass was not found in Japan (Koga 1993; Enomoto et al. 1998). Recent surveys showed that naturalised Italian ryegrasses infected with Neotyphodium endophytes are prevalent in western Japan (Sugawara et al. 2006). In this study, we investigated the distribution of Neotyphodium endophytes in naturalised Italian ryegrass and perennial ryegrass in Japan.

\section{Materials and Methods}

Seeds of naturalised Italian/annual ryegrass were collected from 135 populations in each of the 26 prefectures of Honshu, Shikoku and Kyushu in Japan from 2001 to 2005. Seeds of naturalized perennial ryegrass were collected from 38 populations in each of the 13 prefectures of Honshu, Shikoku, Kyushu and Hokkaido from 2001 to 2005 . The average number of individuals sampled

Figure 2 Endophyte infection rate in seeds of naturalised Italian ryegrass in western Japan. The proportion of each circle shaded in black indicates the percentage of seeds infected. Numbers in parentheses are the numbers of infected populations / surveyed populations.

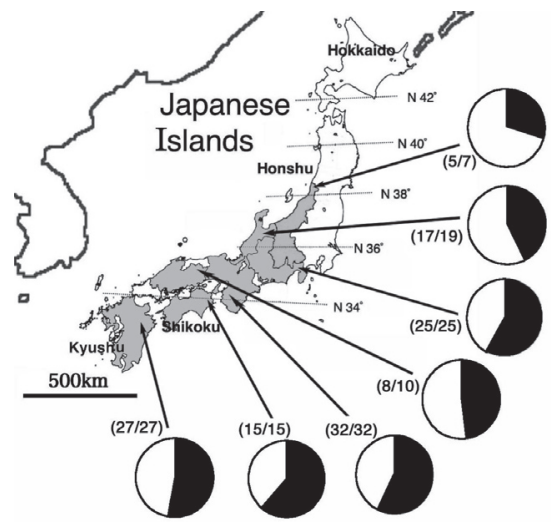


in each population was 31 (range: 10 to 100). Sampling sites were located mainly in open spaces such as riparian areas, roadsides, and vacant lots. Collected seeds were pooled for each population.

Endophyte infection rate was evaluated in about 20 seeds from each population. The presence of intercellular mycelium was checked by microscopic observations, using the method described by Saha et al. (1988).

A chi-square test was performed to detect differences in frequency of endophyte infections among species and among populations. To study relationships between level of endophyte infection and climate in Japan, we used climate data collected near population sampling sites, obtained from AMEDAS records on the websites of Japan Meteorological Agency (http://www. data.kishou.go.jp/). Correlation coefficients between endophyte infection rates and climatic variables were calculated.

\section{Results and Discussion}

Infections by Neotyphodium endophytes were detected in 131 of 135 naturalized Italian/annual ryegrass populations in western Japan. Percentages of infected seeds ranged from $0 \%$ to $100 \%$ (mean $=53 \%$ ). Thirty-one of 38 naturalised perennial ryegrass populations in western and northern Japan were infected by Neotyphodium endophytes (mean infection rate of seeds $=24 \%$ ). Italian ryegrass had a significantly higher infection rate than perennial ryegrass (Fig. 1, $\chi^{2}=286, \mathrm{P}<0.005$ ).

These results suggest that most of naturalised Italian ryegrass populations in western Japan have high rates of Neotyphodium infection. Until recently, endophyte infected Italian ryegrass populations were reported from several regions in the world (Latch et al. 1988; Omachini et al. 2001; 2004; Vila-Aiub et al. 2005), while records from Japan were rare. It was believed that infection rates were very low in Japanese cultivars bred for forage. Sasaki et al. (2000, 2002) showed that Neotyphodium was rare in Italian ryegrass cultivars bred in Japan, but many cultivars bred in other countries were infected. In our study, populations sampled were not located in and around meadows, suggesting that forage cultivars used in meadows are not the source of naturalised Italian ryegrass populations in western Japan. It is probable that other cultivars introduced for turf or soil conservation are the source. It is also possible that the source may be attributed to contaminant seeds in imports of grain or seedstock of other crop species.

There was no geographic variation in perennial ryegrass infection rates (including populations from Hokkaido and western Japan, data not shown). In contrast, infection rates of Italian ryegrass varied on a geographical scale, with a tendency toward a higher frequency of infection in southwestern than in northern Japan (Fig. 2). Significant correlations were obtained between the infection rates in Italian ryegrass and air temperatures of the habitats; the highest correlation was with annual mean minimum temperature $(\mathrm{R}=0.23, \mathrm{P}<0.01)$.

Why is it that geographic variation in infection rate occurs only in Italian ryegrass? The reason is uncertain. Neotyphodiuminfected Italian ryegrass may have been under selection pressures mediated by the differences in weather and other environmental conditions among habitats. The endophyte may enhance fitness of naturalised Italian ryegrass. However, what the benefits are and why they differ in perennial ryegrass populations are issues for future research. There is also a need for research into the role the fungi play in the ecosystem in order to understand how the infected ryegrass populations are introduced and prevail. These are important points of interest for ecologists and agronomists in Japan.
Sugawara et al. (2006) showed that the endophytic fungus present in seeds from 13 naturalised Italian ryegrass populations selected randomly in western Japan was Neotyphodium occultans. The identification was based on the location of hyphae (confined to the basal few millimeters of the leaf sheaths), typical morphology of this species, and agreement of rDNA with the isolates recorded in other countries. Since hyphae of $N$. occultans are confined to the base of the plant leaf sheaths, apical meristems, flowers and seeds, it was thought that the fungus would confer few benefits on mature Italian ryegrass (Latch et al. 1988). Although the species of the endophytic fungus in the Italian ryegrass was not specified, Omacini et al. $(2001,2004)$ suggested that endophytes may affect herbivore food chains and soil organisms and the ecosystem processes they regulate. Vila-Aiub et al. (2005) also showed endophyte-infected Italian ryegrass produced significantly more vegetative tillers and allocated more biomass to roots and seeds than uninfected individuals. It is also thought that endophytes protect plants from seed and seedling predators (Knoch et al. 1993) and that alkaloids function as allelopathic agents (Faeth 2002). Since loline and peramine (insect toxin and feeding deterrent) have been detected in the N. occultans-infected Italian ryegrass seed, and because neither lolitrem B nor ergovaline (causal agents of grazing animal toxicity) occur in some of the populations sampled in this study, the endophyte is expected to be useful for forage crops (Sugawara et al. 2006).

Hybrids can be formed between perennial and Italian ryegrasses. DNA analysis confirmed that some clones considered to have hybrid origin were within the sample investigated in this study (Tobina et al. unpublished). Investigations of endophyte infection rates and infected fungal species in these "hybrids" are at a preliminary stage. An interesting topic for the future will be a study of the ecological mechanisms determining the distribution of $N$. occultans and $N$. lolii within and among infected plant populations.

\section{ACKNOWLEDGEMENTS}

This work was supported in part by Grants-in-Aid for Scientific Research from the Japan Society for the Promotion of Science (JSPS) (No. 18380156).

\section{REFERENCES}

Clay, K.; Holah, J. 1999. Fungal endophyte symbiosis and plant diversity in successional fields. Science 285: 1742-1744.

Enomoto, T.; Shimanuki, T.; Tsukiboshi, T. 1998. The gramineous plants in which Neotyphdium endopyte were found. (In Japanese) Journal of Weed Science and Technology 43 (Suppl): 76-77.

Faeth, S.H. 2002. Are endophytic fungi defensive plant mutualists? Oikos 98: 25-36.

Koga, H. 1993. Endophytic fungi in pasture grasses and imported turf in Japan. (In Japanese) Plant Protection Journal 47: $297-$ 300.

Koga, H.; Kimigafukuro, T.; Tsukiboshi, T.; Uematsu, T. 1993. Incidence of endophytic fungi in perennial ryegrass in Japan. Annals of the Phytopathological Society of Japan 59: 180184.

Knoch, T.R.; Faeth, S.H.; Arnott, D.L. 1993. Endophytic fungi alter foraging and dispersal by desert seed-harvesting ants. Oecologia 95: 470-473.

Latch, G.C.M.; Christensen, M.J.; Hickson, R.E. 1988. Endophytes of annual and hybrid ryegrasses. New Zealand Journal of Agricultural Research 31: 57-63. 
Omacini, M.; Chaneton, E.J. ; Ghersa, C.M.; Muller, C.B. 2001. Symbiotic fungal endophytes control insect host-parasite interaction webs. Nature 409: 78-81.

Omacini, M.; Chaneton, E.J.; Ghersa, C.M.; Otemo, P. 2004. Do foliar endophytes affects grass litter decomposition? A microcosm approach using Lolium multiflorum. Oikos 104: 581-590.

Rudgers, J.A.; Koslow, J.M.; Clay, K. 2004. Endophytic fungi alter relationships between diversity and ecosystem properties. Ecology Letters 7: 42-51.

Rudgers, J.A.; Mattingly, W.B.; Koslow, J.M. 2005. Mutualistic fungus promotes plant invasion into diverse communities. Oecologia 144: 463-471.

Saha, D.; Jackson, M.; Johnson-Cicalese, M. 1988. A rapid staining method for detection of endophytic fungi in turf and forage grasses. Phytopathology 78: 237-239.

Saiga, S.; Inoue, T.; Nakashima, H.; Maeshima, A.; Yoshida, S.; Tuiki, M. 2003. Incidence of Neotyphodium endophytes among naturalized perennial ryegrass and tall fescue plants in northern Japan and alkaloid concentration of the seeds from infected plants. Grassland Science 49: 444-450.

Sasaki, R.; Okazaki, H.; Kasai E. 2000. Research of endophyte infection in commercial cultivars for meadow grass of fescues and ryegrasses. (In Japanese) Grassland Science 46 (Suppl): 160-161.

Sasaki, R.; Okazaki, H.; Kasai E. 2002. Detection rate of endophyte and alkaloid analysis in Italian ryegrass commercial cultivars and strains bred in Japan and abroad. (In Japanese) Grassland Science 48 (Suppl): 264-265.

Sato, N.; Tagawa, M.; Kitamori, T.; Akiyama, N. 1995. Incidence of endophyte fungi on forage grasses in the grassland in northern and central regions of Hokkaido and the prevention methods of infected seeds. Journal of Hokkaido Society of Grassland Science 29: 78-84.

Sugawara, K.; Inoue, T.; Yamashita, M.; Ohkubo, H. 2006. Distribution of the mutualistic endophytic fungus, Neotyphodium occultans in naturalized Italian ryegrass in western Japan and the presence of bioactive alkaloids. Grassland Science 52: 147-154.

Vila-Aiub, M.M.; Gundel, P.E.; Ghersa, C.M. 2005. Fungal endophyte infection changes growth attributes in Lolium multiflorum Lam. Austral Ecology 30: 49-57.

Weiss, S.B. 1999. Cars, cows, and checkerspot butterflies: Nitrogen deposition and management of nutrient-poor grasslands for a threatened species. Conservation Biology 13: 1476-1486. 